\title{
Front Matter: Volume 11100
}

, "Front Matter: Volume 11100," Proc. SPIE 11100, Optomechanical

Engineering 2019, 1110001 (24 September 2019); doi: 10.1117/12.2552149

SPIE Event: SPIE Optical Engineering + Applications, 2019, San Diego, California, SPIE. United States 


\section{PROCEEDINGS OF SPIE}

\section{Optomechanical Engineering 2019}

Keith B. Doyle

Jonathan D. Ellis

Editors

14 August 2019

San Diego, California, United States

Sponsored and Published by

SPIE 
The papers in this volume were part of the technical conference cited on the cover and title page. Papers were selected and subject to review by the editors and conference program committee. Some conference presentations may not be available for publication. Additional papers and presentation recordings may be available online in the SPIE Digital Library at SPIEDigitalLibrary.org.

The papers reflect the work and thoughts of the authors and are published herein as submitted. The publisher is not responsible for the validity of the information or for any outcomes resulting from reliance thereon.

Please use the following format to cite material from these proceedings:

Author(s), "Title of Paper," in Optomechanical Engineering 2019, edited by Keith B. Doyle, Jonathan D. Ellis, Proceedings of SPIE Vol. 11100 (SPIE, Bellingham, WA, 2019) Seven-digit Article CID Number.

ISSN: 0277-786X

ISSN: 1996-756X (electronic)

ISBN: 9781510628939

ISBN: 9781510628946 (electronic)

Published by

SPIE

P.O. Box 10, Bellingham, Washington 98227-0010 USA

Telephone +1 3606763290 (Pacific Time) · Fax +1 3606471445

SPIE.org

Copyright (c) 2019, Society of Photo-Optical Instrumentation Engineers.

Copying of material in this book for internal or personal use, or for the internal or personal use of specific clients, beyond the fair use provisions granted by the U.S. Copyright Law is authorized by SPIE subject to payment of copying fees. The Transactional Reporting Service base fee for this volume is $\$ 21.00$ per article (or portion thereof), which should be paid directly to the Copyright Clearance Center (CCC), 222 Rosewood Drive, Danvers, MA 01923. Payment may also be made electronically through CCC Online at copyright.com. Other copying for republication, resale, advertising or promotion, or any form of systematic or multiple reproduction of any material in this book is prohibited except with permission in writing from the publisher. The CCC fee code is 0277 $786 \mathrm{X} / 19 / \$ 21.00$.

Printed in the United States of America by Curran Associates, Inc., under license from SPIE.

Publication of record for individual papers is online in the SPIE Digital Library.

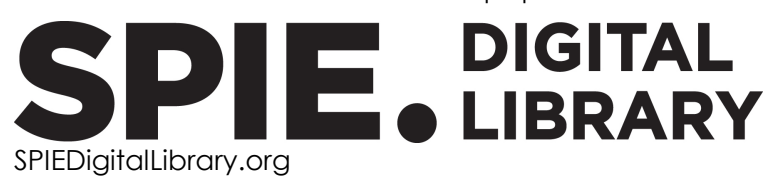

Paper Numbering: Proceedings of SPIE follow an e-First publication model. A unique citation identifier (CID) number is assigned to each article at the time of publication. Utilization of CIDs allows articles to be fully citable as soon as they are published online, and connects the same identifier to all online and print versions of the publication. SPIE uses a seven-digit CID article numbering system structured as follows:

- The first five digits correspond to the SPIE volume number.

- The last two digits indicate publication order within the volume using a Base 36 numbering system employing both numerals and letters. These two-number sets start with 00, 01, 02, 03, 04, 05, 06, 07, 08, 09, OA, OB ... 0Z, followed by 10-1Z, 20-2Z, etc. The CID Number appears on each page of the manuscript. 


\section{Contents}

$\begin{array}{ll}\vee & \text { Authors } \\ \text { vii } & \text { Conference Committee }\end{array}$

SESSION 1 OPTOMECHANICAL DESIGN AND OPTIMIZATION

1110002 Optomechanical design considerations for a vacuum window for optical and infrared interferometry [1 $11100-1]$

1110003 Development of a mirror mount suitable for laboratory and OEM applications [1 11 100-2]

1110004 Design and test of a compound curved beam flexure with off-axis actuation for precision optical alignment [ $111100-3]$

1110005 Optomechanical design of a portable metrology system for measurement of precision rotary stage errors [1 $1100-4]$

1110006 The optomechanical design for the Off-plane Grating Rocket Experiment (OGRE) [1 $1100-5]$

$1110007 \quad$ Structural optimization of system WFE [1 $11100-6]$

1110008 Global optimization using LLIMAS for the design of vibration isolation systems of highuncertainty payloads [1 $11100-8]$

$1110009 \quad$ Mirror topology optimization [11100-25]

\section{SESSION 2 OPTOMECHANICAL ANALYSIS}

$11100 \mathrm{OA} \quad$ Obtaining finite element thermal loads from fluence maps and voxels [1 $11100-9]$

$11100 \mathrm{OB} \quad$ Finite element modeling of a laminar flexure bending mechanism for elliptically bent hard x-ray mirror [1 $11100-10]$

SESSION 3 OPTOMECHANICAL SYSTEMS, MECHANISMS, AND DEVICES

$11100 \mathrm{OE} \quad$ System engineering of complex optical systems: requirements and verification documents [11100-13]

11100 OG Anomalous behavior of Transiting Exoplanet Survey Satellite (TESS) optical assembly: root cause investigation reveals crystallization of RTV $\mathbf{5 6 6}$ at low temperatures [1 $1100-15]$ 
$11100 \mathrm{OH} \quad$ High loading precision rotation stage design for synchrotron radiation mirror stitching measurement [1 $11100-16]$

$111000 \mathrm{Ol} \quad$ Using a digital still camera for shearography: preliminary experiments and observations [11 100-18]

\section{POSTER SESSION}

11100 0J Design and development of large SiC mirror for spaceborne application [1 $1100-19]$

$11100 \mathrm{OL} \quad$ Conceptual and test phase of optical design of seeker in missile application [11100-21]

11100 OM Effect of beam steering method on optical system [1 $1100-22]$

$111000 \mathrm{~N} \quad$ Design of dual mode seeker for millimeter wave and four-quadrant detectors in missile application [1 $11100-23]$

1110000 Stabilization effects on seeker performance in missile application [1 1100-24] 


\title{
Authors
}

Numbers in the index correspond to the last two digits of the seven-digit citation identifier (CID) article numbering system used in Proceedings of SPIE. The first five digits reflect the volume number. Base 36 numbering is employed for the last two digits and indicates the order of articles within the volume. Numbers start with 00, 01, 02, 03, 04, 05, 06, 07, 08, 09, OA, OB...0Z, followed by 10-1Z, 20-2Z, etc.

\author{
Abedin, Kazi Monowar, 0 I \\ Ahmad, Anees, OE \\ Al Jabri, Awatif Rashid, 0 l \\ Al Shidhani, Saleh Said, 01 \\ Allgood, Kim D., 06 \\ Anton, Jayson W. J., OB \\ Assoufid, Lahsen, $\mathrm{OB}$ \\ Biskach, Michael P., 06 \\ Bisson, Gary, 07, 0A \\ Chan, Kai-Wing, 06 \\ Chen, Bo-Yi, OH \\ Clark, James H., III., 02 \\ Cox, Brian C., 04 \\ De Andrade, Vincent, 05 \\ DeWitt, Frank A., 03 \\ Donovan, Benjamin D., 06 \\ Doyle, Keith B., OG \\ Fung, Hok-Sum, $\mathrm{OH}$ \\ Genberg, Victor L., 07, OA \\ Harder, Ross, OB \\ Hlinka, Michal, 06 \\ Holland, Andrew D., 06 \\ Holland, Karen, 06 \\ $\mathrm{Hsu}$, Ming-Ying, $\mathrm{OH}$ \\ Huang, Yu-Shan, $\mathrm{OH}$ \\ Kearney, John D., 06 \\ Kearney, Steven P., 05, OB \\ Lee, Chien-yu, $\mathrm{OH}$ \\ Lee, Yun Woo, OJ \\ Lewis, Matthew R., 06 \\ Lin, Shang-Wei, $\mathrm{OH}$ \\ Maser, Jörg, 05 \\ Mashrafi, Sheikh T., OB \\ Mazzarella, James R., 06 \\ McEntaffer, Randall L., 06 \\ Michels, Gregory J., 07, OA \\ Moon, II Kweon, OJ \\ Mooney, Tim M., OB \\ Mower, Todd M., OG \\ Murray, Neil J., 06 \\ Mutters, David K., 09 \\ Numata, Ai, 06 \\ O'Meara, Bridget C., 06 \\ Penado, F. Ernesto, 02 \\ Qian, Jun, OB \\ Rahman, S.M. Mujibur, OI \\ Rey, J., 08 \\ Riveros, Raul E., 06 \\ Saha, Timo T., 06
}

Sakarya, Doğan Uğur, OL, OM, ON, 00

Sari, Hüseyin, OL, OM, ON, 00

Schultz, Ted B., 06

Shi, Bing, OB

Shi, Xianbo, OB

Shu, Deming, 05, OB

Solly, Peter, 06

Soman, Matthew R., 06

Stoeckel, G., 08

Tutt, James H., 06

Wang, Duan-Jen, $\mathrm{OH}$

Wellman, John A., OG

Yang, Ho-Soon, OJ

Yin, Gung-Chian, $\mathrm{OH}$

Zhang, William W., 06 
Proc. of SPIE Vol. 11100 1110001-6

Downloaded From: https://www.spiedigitallibrary.org/conference-proceedings-of-spie on 26 Apr 2023 Terms of Use: https://www.spiedigitallibrary.org/terms-of-use 


\section{Conference Committee}

Program Track Chair

H. Philip Stahl, NASA Marshall Space Flight Center (United States)

Conference Chairs

Keith B. Doyle, MIT Lincoln Laboratory (United States)

Jonathan D. Ellis, College of Optical Sciences, The University of Arizona (United States)

Conference Program Committee

Anees Ahmad, Raytheon Missile Systems (United States)

James H. Burge, College of Optical Sciences, The University of Arizona (United States)

John M. Casstevens, Dallas Optical Systems, Inc. (United States)

Patrick A. Coronato, Raytheon Missile Systems (United States)

John G. Daly, Vector Engineering (United States)

Victor L. Genberg, Sigmadyne, Inc. (United States)

Mark J. Hegge, Ball Aerospace \& Technologies Corporation (United States)

Tony Hull, University of New Mexico at Albuquerque (United States)

Frank W. Kan, Simpson Gumpertz \& Heger Inc. (United States)

Keith J. Kasunic, Optical Systems Group, LLC (United States)

William Jeffrey Lees, Johns Hopkins University Applied Physics Lab., LLC (United States)

John W. Pepi, L3 Technologies, Inc. (United States)

John J. Polizotti, BAE Systems (United States)

Deming Shu, Argonne National Laboratory (United States)

Daniel Vukobratovich, Raytheon Missile Systems (United States)

Carl H. Zweben, Consultant (United States)

\section{Session Chairs}

1 Optomechanical Design and Optimization

Deming Shu, Argonne National Laboratory (United States)

Mark J. Hegge, Ball Aerospace (United States)

2 Optomechanical Analysis

Frank W. Kan, Simpson Gumpertz \& Heger Inc. (United States)

3 Optomechanical Systems, Mechanisms, and Devices

Anees Ahmad, Raytheon Missile Systems (United States) 
Proc. of SPIE Vol. $111001110001-8$

Downloaded From: https://www.spiedigitallibrary.org/conference-proceedings-of-spie on 26 Apr 2023 Terms of Use: https://www.spiedigitallibrary.org/terms-of-use 